Pregledni rad

\title{
ANALIZA PRIMJENE METODE ANALITIČKOG MREŽNOG PROCESA ANP U SUSTAVIMA ZA E-UČENJE
}

\section{Maja Gligora Marković}

Dr. sc., asistentica, Sveučilište u Rijeci, Medicinski fakultet, Braće Branchetta 20, 51000 Rijeka, Hrvatska; e-mail:majagm@medri.uniri.hr

\section{SAŽETAK}

Cilj je ovim radom istražiti pojavnost korištenja metode analitičkog mrežnog procesa u sustavima za e-učenje kao metode za donošenje odluke temeljem više kriterija. Pretražene su znanstvene baze Scopus i WOS (Web of Science) prema odabranim ključnim riječima: „analytic network process“ i „e-learning system", radovi koji su u otvorenom pristupu i u cijelosti na engleskom jeziku. Pronađena su 23 članka, od čega su dva članka bila indeksirana u obje baze pa se analiza temelji na 21 članku. Radovi su analizirani prema godini objave, državi prebivališta autora, broju izvora korištenih u pisanju radova, prosječnom broju autora koji su sudjelovali u izradi rada, publikaciji objave članaka te je izvršena kvalitativna analiza sadržaja radova o primjeni metode analitičkog mrežnog procesa ANP (engl. Analytic Network Process) u sustavima za e-učenje. Najviše je objavljenih radova u 2018. i 2020. godini, najčešća je država prebivališta autora Tajvan, a prosječan je broj autora po jednom radu 4. Kvalitativnom analizom sadržaja izdvojenih radova utvrđeno je da ni u jednom sustavu metoda ANP nije ugrađena u sam sustav već se navedena metoda koristi u istraživanjima vezanim uz evaluaciju sustava ili identifikaciju parametara potrebnih za njihovu izgradnju ili u nekom dijelu istraživanja koje uključuje sustav za e-učenje.

Ključne riječi: analitički mrežni proces, ANP, sustavi za e-učenje, e-učenje, metode višekriterijskog odlučivanja

\section{UVOD}

Danas je, više nego ikad, u fokusu globalne pandemije virusom COVID-19, osim zdravstvene djelatnosti, sektor obrazovanja od iznimne važnosti. Obrazovanje u digitalnom dobu na daljinu podrazumijeva korištenje sustava za e-učenje. „Sustavi za e-učenje su sustavi koji studentima omogućavaju pristup izvorima za učenje u elektroničkom obliku, a da pri tom nema prostornih $\mathrm{i}$ vremenskih ograničenja." (Gligora Marković, 2020. prema Albert, 2001). 
S obzirom na razvoj digitalne tehnologije danas imamo sustave za e-učenje koji se svojim funkcionalnostima prilagođavaju korisnicima prema nekim kriterijima prilagodbe. $U$ procesu prilagođavanja u sustavima za e-učenje potrebno je donijeti odluku o prilagodbi prema nekim kriterijima. Najčešći je kriterij prilagodbe znanje (Gligora Marković, Kadoić, Kovačić, 2018) i koriste se jednostavna pravila prilagodbe u sustavima za e-učenje. Međutim ukoliko želimo kvalitetnije i učinkovitije sustave, potrebno je uključiti više kriterija i donijeti odluku na temelju više njih, dakle primijeniti neku od metoda višekriterijskog odlučivanja. Najpoznatije metode višekriterijskog odlučivanja jesu: ELECTRE, TOPSIS, PROMETHEE, AHP, ANP, LINANP itd. (Sikavica et al., 2014; Đurek, Sedda, 2020. prema Kadoić et al., 2016).

Cilj je ovim istraživanjem bilo utvrditi pojavnost korištenja metode ANP u sustavima za e-učenje s obzirom na to da je u procesu prilagodljivosti sustava za e-učenje korisniku potrebno donijeti odluku o načinu i kriterijima prilagodbe sustava.

„Metoda analitički mrežni proces (ANP) predstavlja metodu višekriterijskog odlučivanja kod koje osim informacija o kriterijima za donošenje odluke su nam potrebne i informacije o alternativama" (Gligora Marković, 2020). U sustavima za e-učenje kriteriji su vezani uz prilagodbu korisniku i nekim njegovim preferencijama dok alternative najčěće predstavljaju aktivnosti koje korisnik može provoditi u sustavu i/lii objekte učenja (resursi za učenje) koji predstavljaju najmanju jedinicu sadržaja učenja. Metoda ANP jedna je od rijetkih metoda koja u obzir uzima zavisnost među kriterijima i povratnu vezu između alternativa i kriterija te je zbog toga veći izazov primijeniti je.

\section{METODOLOGIJA ISTRAŽIVANJA}

Provedeno je istraživanje tijekom studenog 2020. koje je uključivalo pretraživanje baza podataka Web of Science (all databases) i Scopus prema sljedećim kriterijima pretrage: ključne riječi u pretrazi bile su „analytic network process" i „e-learning system“ kao pojmovi koji obuhvaćaju potpuno ime metode ANP i sustavi za e-učenje kao krovni pojam za sve specifične podvrste sustava čija je namjena podrška poučavanju i učenju te kriterij otvorena pristupa izvoru (članku). Baze korištene u istraživanju odabrane su iz razloga jer su to baze relevantne za izbor u znanstvena zvanja Republike Hrvatske (Pravilnik o izboru u znanstvena zvanja, 2017), ali i inače baze priznate u znanstvenoistraživačkom svijetu. Pristup bazama podataka osiguran je preko nadležnog Ministarstva znanosti i obrazovanja putem portala Nacionalne i sveučilišne knjižnice u Zagrebu (http://baze.nsk.hr/oportalu/). Osim ključnih riječi i otvorenog pristupa primijenjen je i kriterij engleskog jezika kao jezika na kojem je rad napisan te period objave otkad baze postoje do danas. Tako definiranom pretragom pronađena su 23 članka. Uspoređeni su naslovi članaka gdje je utvrđeno da su dva članka indeksirana u obje baze te je time sužen rezultat na 21 rad, na čijem se broju temelji daljnja analiza. Radovi su analizirani prema godini objave, državi prebivališta autora, afilijaciji autora, broju autora rada, broju korištenih izvora, objavi u časopisu ili konferenciji te je provedena kvalitativna analiza sadržaja radova $s$ fokusom na opis primjene metode ANP u sustavima za e-učenje. Prikupljeni podatci pohranjeni su i obrađeni pomoću alata Excel 2016. Na slici 1. prikazana je metodika istraživanja. 
Slika 1. Metodika istraživanja

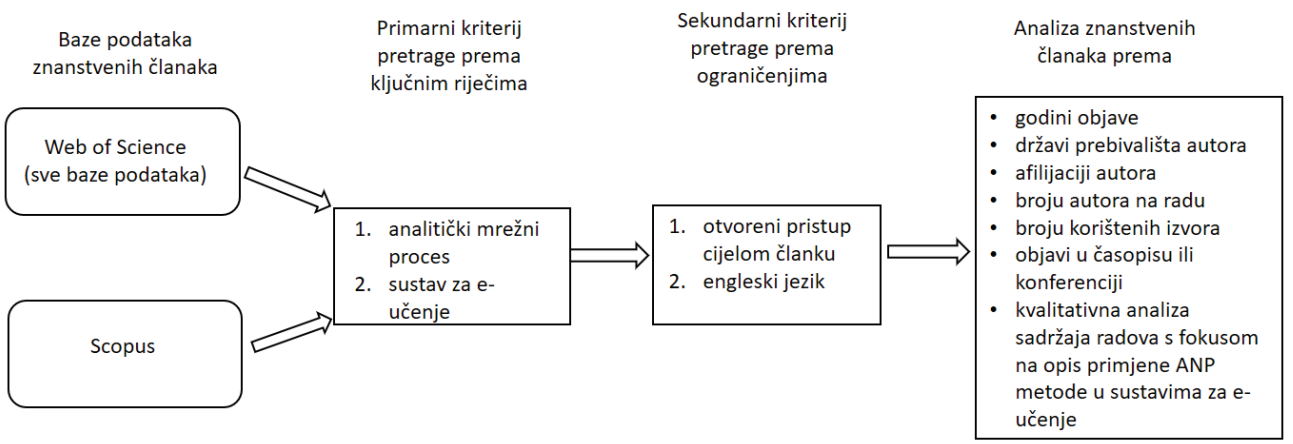

Izvor: autor

\section{REZULTATI ISTRAŽIVANJA S DISKUSIJOM}

Pretraga je rezultirala s ukupno 23 članka, i to 7 članaka pronađeno je u bazi WOS (all databases) i 16 članaka u bazi Scopus. Dva su članka indeksirana u obje baze pa se analiza temelji na 21 članku. U tablici 1 prikazana je pojavnost radova prema godini objave za 21 članak.

Tablica 1. Pojavnost broja radova prema godini objave

\begin{tabular}{|l|c|}
\hline godina objave & pojavnost \\
\hline 2011. & 1 \\
\hline 2012. & 3 \\
\hline 2013. & 0 \\
\hline 2014. & 0 \\
\hline 2015. & 2 \\
\hline 2016. & 2 \\
\hline 2017. & 2 \\
\hline 2018. & 5 \\
\hline 2019. & 2 \\
\hline 2020. & 4 \\
\hline
\end{tabular}

Izvor: autor

Možemo uočiti da je najviše radova objavljeno u 2018. i 2020. godini iako još 2020. u trenutku analize nije završila pa se može očekivati da će biti još radova iz teme pretrage jer znamo da bazama treba određeno vrijeme za indeksiranje publikacija.

Analizom država prebivališta autora uočeno je da su u svim člancima u kojima je više autora, osim u jednom, autori iz iste zemlje. Na slici 2. prikazana je pojavnost država prebivališta autora. 
Slika 2. Pojavnost broja autora prema državi prebivališta

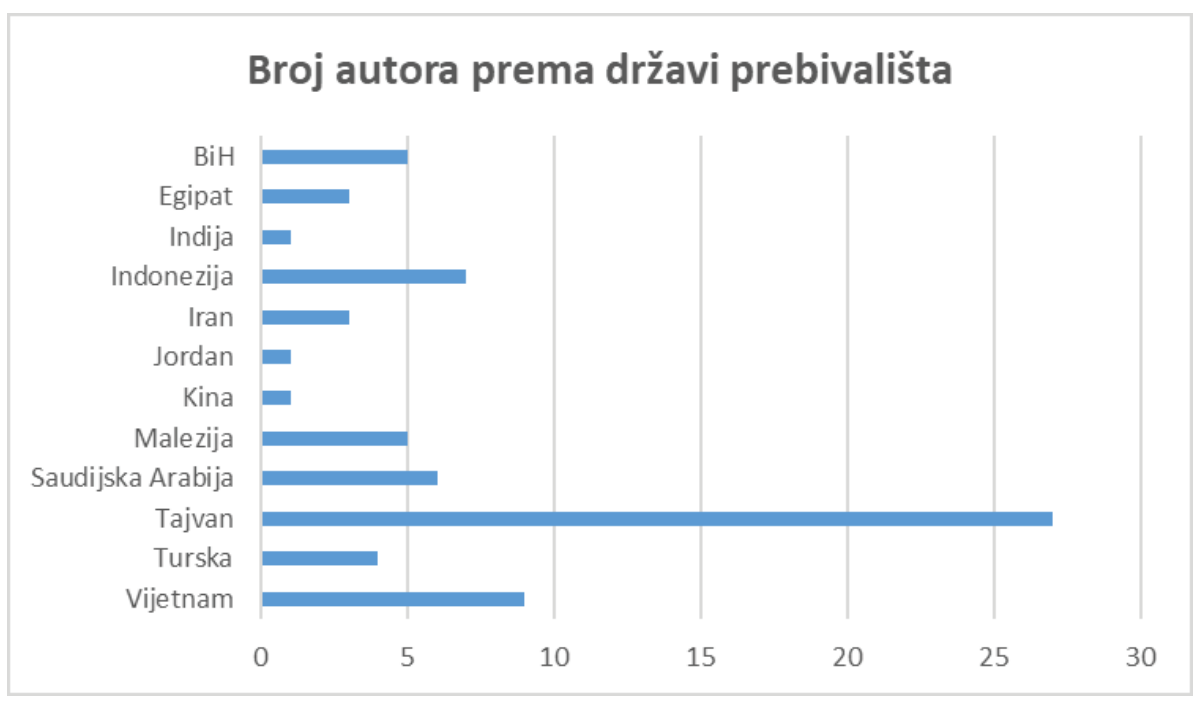

Izvor: autor

Analiziramo li pojavnost pojedine države, možemo uočiti dominaciju Tajvana, nakon čega slijede Vijetnam i Indonezija. I u rijetkim prethodnim istraživanjima (Gligora Marković, Jakupović, Kovačić, 2014) može se uočiti dominacija zemalja iz Azije. Jedan je od mogućih razloga razvijena industrija digitalne tehnologije u odnosu na zemlje zapadnog svijeta.

U izradi ovog 21 rada sudjelovalo je ukupno 77 autora, odnosno 3,666 autora po radu, što govori u prilog složenosti teme (pretrage) i potrebe angažmana većeg broja znanstvenika u njihovoj izradi. Svi autori kao afilijaciju navode sveučilište ili visoke škole.

Ukupno je korišteno 952 izvora u izradi 21 članka, što je u prosjeku 47,6 izvora po radu, a medijan broja izvora po članku iznosi 39.

Na slici 3. prikazana je relativnim brojem zastupljenost publikacije objave članka. $U$ časopisima je objavljeno 20 radova, a u zborniku konferencije 1 rad. S obzirom na to koje su baze bile uključene $\mathrm{u}$ istraživanje, rezultat je očekivan jer te baze indeksiraju više časopisa nego zbornika konferencija. 
Slika 3. Broj članaka prema publikaciji objave

\section{Broj članaka prema publikaciji objave}

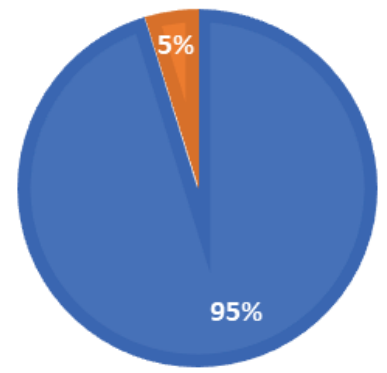

- časopis

konferencija

Izvor: autor

U nastavku slijedi kvalitativna analiza korištenja metode ANP opisane u radovima, a dobivena pretragom baza SCOPUS i WOS. U 2 rada (Yu et al., 2020; Yen et al., 2015) metoda ANP uopće se ne spominje, što daje razlog za razmišljanje na koji način baze izvršavaju pretragu radova koje indeksiraju te koliko ključne riječi stvarno odražavaju sadržaj radova. U radovima ključne riječi definiraju autori, ali i baze same imaju dodatne ključne riječi kojima se opisuju radovi.

U preostalih 19 radova metoda ANP korištena je $u$ istraživačkom procesu, međutim ni u jednom od radova navedena metoda nije ugrađena u sam sustav kao mehanizam za donošenje nekih odluka već je na različite načine upotrijebljena tijekom opisanih istraživanja.

Gotovo polovica autora u svojim radovima spominju metodu ANP u kontekstu metoda višekriterijskog odlučivanja posebno u usporedbi s metodom AHP (engl. Analytic Hierarcy Process), kojoj je metoda ANP nadogradnja na način da se u odlučivanju umjesto hijerarhijske strukture klastera i pripadajućih čvorova karakterističnih za metodu AHP koristi mrežna struktura karakteristična za ANP (Hsieh et al., 2012; Hu, 2016; Naveed et al., 2019; Alzubi et al., 2018; Kustiyahningsih et al., 2020; Kustiyahningsih et al., 2018; Stević et al., 2018; Idrees et al., 2019).

Tako autori Rahmanita et al. (2018), Yang et al. (2012), Etaati et al. (2011) i Abdullateef et al. (2016) metodu ANP koriste u svrhu procjene kvalitete sustava ili nekih njegovih dijelova kako bi identificirali ili odredili težinske faktore parametara koji opisuju kvalitetu sustava te na temelju toga donijeli odluku o daljnjem upravljanju sustavom.

Neki od autora u svojim radovima koriste metodu ANP u svrhu identifikacije parametara potrebnih za izgradnju sustava za e-učenje (Yang et al., 2018; Huynh, 2020; Nguyen, 2020) dok rijetki koriste za evaluaciju edukativnih mrežnih sjedišta (Kabak, 2017). Ostali autori, npr. Chuang (2015), koriste metodu ANP u istraživanju parametara vezanih uz bihevioralnu znanost, čiji se rezultati mogu koristiti u različitim sustavima koji uključuju ljude kao korisnike, odnosno kod procjena sljedivosti informacija u sustavima na primjeru ponašanja potrošača u sustavu (Chen, 2012). 


\section{ZAKLJUČAK}

Provedeno istraživanje obuhvatilo je najrelevantnije znanstvene baze podataka - WOS i SCOPUS. Pretraga je izvršena s pojmovima koji obuhvaćaju puni naziv metode ANP (engl. Analytic Network Process) i pojmom sustavi za e-učenje (engl. E-learning system) kao pojmom koji obuhvaća različite vrste sustava za učenje poput hipermedijskih, prilagodljivih, inteligentnih itd. Rezultati su pokazali da je najviše radova objavljeno zadnjih godina (2018. i 2020.), što je s obzirom na razvoj tehnologije i očekivano. Najveći je broj autora radova iz država Azije (Tajvan), što je u skladu s prethodnim istraživanjima. Neočekivan je dio što metoda ANP nije ugrađena ni u jedan sustav za e-učenje. Mogući nastavak budućeg istraživanja jest da se proširi broj baza za pretragu i na baze koje su, prema Pravilniku za izbor u znanstvena zvanja (2017), u rangu A2 radova, odnosno da se pretražuju i radovi koji nisu dostupni u otvorenom pristupu s obzirom na to da smo upoznati s činjenicom da je trošak objave rada u časopisima koji su indeksirani u relevantnim bazama najčěšce izuzetno visok. Osim povećanja broja baza u planu je uključiti i veći broj ključnih riječi za pretragu s obzirom na to da ovako dva opća pojma korištena u istraživanju nisu baš polučila očekivani rezultat.

Ovaj rad je sufinancirala Hrvatska zaklada za znanost projektom UIP-2020-02-6312.

\section{LITERATURA}

Abdullateef, B.N., Elias, N.F., Mohamed, H., Zaidan, A.A., Zaidan, B.B. (2016) „An evaluation and selection problems of OSS-LMS packages", SpringerPlus, 5(1), pp. 1-35

Albert, D. (2001) E-learning future - The contribution of psychology. In R. Roth, L. Lowenstein, i D. Trent (Eds.),

Catching the future: Women and men in global psychology, proceedings of the 59th annual convention, international council of psychologists (pp. 30-53). England: Winchester

Alzubi, J., Nayyar, A., Kumar, A. (2018) „Machine Learning from Theory to Algorithms: An Overview“, Journal of Physics: Conference Series, vol. 1142, Bangalore, INDIA, doi: 10.1088/1742-6596/1142/1/012012

Chen, Y., Wang, T., Chen, C., Huang, Y., Wang, C. (2012) „Consumer preferences for information on Taiwan's pork traceability system“, Information Technology Journal, 11(9), pp. 1154-1165

Chuang, H., Lin, C., Chen, Y. (2015), „Exploring the triple reciprocity nature of organizational value cocreation behavior using multicriteria decision making analysis", Mathematical Problems in Engineering, vol. 2015

Đurek, V., Sedda, C. (2020) „Primjena metoda odlučivanja u lokalnoj samoupravi“, Zbornik Veleučilišta u Rijeci, 8(1), str. 203-226, https://doi.org/10.31784/zvr.8.1.20

Etaati, L., Sadi-Nezhad, S., Makue, A. (2011) „Using Fuzzy Group Analytical Network Process and ISO 9126 quality model in software selection: A case study in E-learning systems", Journal of Applied Sciences, 11(1), pp. 96-103

Gligora Marković, M., Jakupović, A., Kovačić, B. (2014) Identification and Analysis of Characteristics of Intelligent and Adaptive Hypermedia E- learning Systems// Recent Advances in Educational

Technologies and Methodologies / Mastorakis, Nikos E., Bojković, Zoran, Rudas, Imre J. (ur.), Lisbon: WSEAS, pp. 34-45

Gligora Marković, M., Kadoić, N., Kovačić, B. (2018) Selection and prioritization of adaptivity criteria in intelligent and adaptive hypermedia e-learning systems, TEM Journal, 7(1), pp. 137-146, doi:10.18421/TEM71-16

Gligora Marković, M. (2020) „Sustav za dinamičko generiranje objekata učenja kao potpora individualno personaliziranoj nastavi", doktorska disertacija, Odjel za informatiku Sveučilišta u Rijeci, Rijeka 
Hsieh, T. C., Wang, T., Su, C.Y., Lee, M. C., (2012) „A Fuzzy Logic-based Personalized Learning System for Supporting Adaptive English Learning", Educational Technology \& Society, 15(1), pp. 273-288

Hu, C., (2016), „Application of E-Learning Assessment Based on AHP-BP Algorithm in the Cloud Computing Teaching Platform", International Journal of Emerging Technologies inLlearning, 11(8), pp. 27-32, doi: 10.3991/ijet.v11i08.6039

Huynh, V.D.B., Nguyen, P.T., Nguyen, Q.L.H.T.T., Vu, N.B. (2020) „E-learning evolution and development from the perspectives of technology, education, and economy", Research in World Economy, 11(1), pp. 11-19

Idrees, A.M., ElSeddawy, A.I. Zeidan, M.O. (2019) „Knowledge discovery based framework for enhancing the house of quality", International Journal of Advanced Computer Science and Applications, 10(7), pp. 324-332

Kabak, M., Ozceylan, E., Dagdeviren, M. \& Genc, T. (2017) „Evaluation of distance education websites: A hybrid multicriteria approach", Turkish Journal of Electrical Engineering and Computer Sciences, 25(4), pp. 2809-2819

Kustiyahningsih, Y., Fatmawati i Suprajitno, H. (2018) "MCGDM with AHP based on Adaptive interval Value Fuzzy“, Telkomnika (Telecommunication Computing Electronics and Control), 16(1), pp. 314-322

Kustiyahningsih, Y., Fatmawati i Suprajitno, H. (2020) „Adaptive Interval Trapezoid Fuzzy Number for Recommendation Systems E-Learning", Journal of Physics: Conference Series

Naveed, Q. N., Qureshi, M. R. N. M., Shaikh, A., Alsayed, A. O., Sanober, S., Mohiuddin, K. (2019), „Evaluating and Ranking Cloud-Based E-Learning Critical Success Factors (CSFs) Using Combinatorial Approach", IEEE ACCESS, vol. 7., doi: 10.1109/ACCESS.2019.2949044

Nguyen, Q.L.H.T.T., Nguyen, P.T., Huynh, V.D.B., Nguyen, L.T. (2020) „Application Chang's extent analysis method for ranking barriers in the e-learning model based on multi-stakeholder decision making", Universal Journal of Educational Research, 8(5), pp. 1759-1766

Pravilnik o uvjetima za izbor u znanstvena zvanja (Narodne novine, br. 28/17., 72/19.)

Rahmanita, E., Prastiti, N. Purnomo, M. (2018) „Measurement Of E-Learning Quality Based On ISO 19796-1

Using Fuzzy Analytical Network Process Method", INTERNATIONAL CONFERENCE ON SCIENCE AND APPLIED SCIENCE (ICSAS) 2018., Conference Proceedings, vol. 2014., Surakarta, Indonesia

Sikavica, P., Hunjak, T., Begičević Ređep, N., Hernaus, T. (2014), Poslovno odlučivanje, Zagreb, Školska knjiga

Stević, Ž., Stjepanović, Ž., Božičković, Z., Das, D.K., Stanujkić, D. (2018) „Assessment of conditions for implementing information technology in a warehouse system: A novel fuzzy PIPRECIA method", Symmetry, 10(11)

Yang, C., Shieh, M., Huang, C., Tung, C. (2018) „A derivation of factors influencing the successful integration of corporate volunteers into public flood disaster inquiry and notification systems", Sustainability (Switzerland) 10(6), pp. 1-31

Yang, L., Chen, J., Huang, C., (2013) „A comprehensive framework for evaluating key project requirements,"Journal of Civil Engineering and Management, 19(1), pp. S91-S105

Yang, M. H., Su, C. H., Wang, W. C., (2017) „The Use of a DANP with VIKOR Approach for Establishing the Model of E-Learning Service Quality", Eurasia Journal of mathematics science and

Technology education, 13(13), pp. 5927-5937, doi: 10.12973/eurasia.2017.01041a

Yang, M., Su, C., Wang, W. (2017) „The use of a DANP with VIKOR approach for establishing the model of e-learning service quality", Eurasia Journal of Mathematics, Science and Technology Education, 13(8),

pp. 5927-5937

Yen, C. H., Chen, I.C., Lai, S.C., Chuang, Y.R. (2015) „An Analytics-Based Approach to Managing Cognitive Load by Using Log Dana of Learning Management Systems and Footprints of Social Media", Educational Technology \& Society, 18(4), pp. 141-158

Yu, C., Chen, K., Lai, K., Hsu, C. (2020) „Fuzzy supplier selection method based on smaller-the-better quality Characteristic“, Applied Sciences (Switzerland), 10(10)

Yu, C., Lai, K., Chen, K., Chang, T. (2020) „Process-Quality Evaluation for Wire Bonding with Multiple Gold Wires", IEEE Access, 8, pp. 106075-106082 


\title{
ANALYSIS OF THE APPLICATION OF THE ANALYTICAL NETWORK PROCESS (ANP) METHOD IN E-LEARNING SYSTEMS
}

\author{
Maja Gligora Marković \\ PhD, Asisstant, University of Rijeka, Faculty of Medicine, Braće Branchetta 20, 51000 Rijeka, Croatia; \\ e-mail:majagm@medri.uniri.hr
}

\begin{abstract}
The Scopus and Web of Science scientific databases were searched according to the selected keywords: "analytical network process" and "e-learning system", papers that are in open access and entirely in English. 23 articles were found, of which two articles were indexed in both databases, so the analysis is based on 21 articles. The papers were analyzed according to the year of publication, country of residence of the author, number of sources used in writing the paper, average number of authors who participated in the preparation of the paper, publication of articles and qualitative analysis of the content of papers on the application of Analytical Network Process) methods in e-learning systems. The most published papers are in 2018 and 2020, the most common country of residence of the authors is Taiwan, and the average number of authors per paper is 4. Qualitative analysis of the content of selected papers found that in no system ANP method is built into the system itself. in research related to system evaluation or identification of parameters required for their construction or in some part of research involving an e-learning system.
\end{abstract}

Key words: analytical network process, ANP, e-learning systems, e-learning, multicriteria decisionmaking methods 